Mosher, B. A., P. F. Doherty, Jr., J. L. Atwood, K. A. Corey, and C. T. Collins. 2021. Evidence of long-term declines in Island Scrub-Jay vital rates. Avian Conservation and Ecology 16(2):21. https://doi.org/10.5751/ACE-01997-160221

Copyright (C) 2021 by the author(s). Published here under license by the Resilience Alliance.

Research Paper

\title{
Evidence of long-term declines in Island Scrub-Jay vital rates
}

Brittany A. Mosher ${ }^{1}$, Paul F. Doherty, Jr. ${ }^{2}$, Jonathan L. Atwood ${ }^{3}$, Kennon A. Corey ${ }^{4}$ and Charles T. Collins ${ }^{5}$

${ }^{1}$ Rubenstein School of Environment and Natural Resources, University of Vermont, ${ }^{2}$ Department of Fish, Wildlife, and Conservation Biology, Colorado State University, ${ }^{3}$ Massachusetts Audubon Society, ${ }^{4}$ Independent Researcher, ${ }^{5}$ California State University, Long Beach

ABSTRACT. Island species play important roles in local ecosystems, but they are undergoing unprecedented rates of extinction from a variety of threats including emerging infectious disease, invasive species, and climate change. These threats are of particular concern for island species because island species often have limited genetic or geographic ability to escape these threats. Little is known about the long-term population trends of the Island Scrub-Jay (Aphelocoma insularis), a species endemic to Santa Cruz Island in California's Channel Islands. We used a 20-year mark-resight dataset to describe long-term trends in Island Scrub-Jay adult population growth, survival, and recruitment, and to relate those trends to major drivers of island endemic extinctions (including disease, invasive species, and climate change). We used a variance components analysis to separate sampling and process variance and identified population declines of $\sim 1.8 \%$ annually that were driven by a reduction in adult survival in the later years of the study. Although we found little evidence for impacts of disease and climate, we found some evidence that observed declines coincided with timing of an increasing wild turkey population but were not correlated with feral sheep or pig presence or eradication. We discuss these findings in the context of previous population estimates for this species and current management actions being considered to conserve the Island Scrub-Jay.

\section{Indication d'une baisse de longue date des taux vitaux du Geai de Santa Cruz}

RESUME_. Les espèces insulaires jouent un rôle important dans les écosystèmes locaux, mais leur taux de disparition est sans précédent en raison de diverses menaces, dont les maladies infectieuses émergentes, les espèces envahissantes et les changements climatiques. Ces menaces sont particulièrement préoccupantes chez les espèces insulaires, car ces dernières ont souvent une capacité génétique ou géographique limitée pour échapper à ces menaces. On sait peu de choses sur les tendances de longue date de la population du Geai de Santa Cruz (Aphelocoma insularis), espèce endémique de l'île Santa Cruz dans les Channel Islands de Californie. Nous avons utilisé un jeu de données de marquage-réobservation sur 20 ans pour décrire les tendances de longue date de la croissance de la population, de la survie et du recrutement chez le Geai de Santa Cruz, et pour relier ces tendances aux principaux facteurs de disparition d'espèces endémiques insulaires (y compris les maladies, les espèces envahissantes et les changements climatiques). Nous avons utilisé une analyse des composantes de la variance pour séparer la variance attribuable à l'échantillonnage de celle liée au processus, et avons trouvé une baisse de population de $\sim 1,8 \%$ par année imputable à une réduction de la survie des adultes au cours des dernières années de l'étude. Bien que peu d'effets des maladies ou du climat aient été observés, nous avons constaté que la baisse de population coïncidait avec une augmentation de la population de dindons sauvages, mais n'était pas corrélée à la présence ou à l'éradication des moutons ou des porcs sauvages. Nous analysons ces résultats dans le contexte des estimations antérieures de population du Geai de Santa Cruz et des mesures de gestion actuellement envisagées pour conserver cette espèce.

Key Words: Aphelocoma insularis; island endemic; population decline; variance components

\section{INTRODUCTION}

Islands generally have fewer species than mainland areas of similar size, and have fewer functionally redundant species (MacArthur and Wilson 1967). Therefore, island species tend to play important and irreplaceable roles in their local ecosystems. Some island species are generalist endemics that, if lost, can disrupt key ecological processes such as seed dispersal, pollination, predation, or nutrient cycling (Olesen et al. 2002, Whittaker and Fernández-Palacios 2007). As a result, the extinction of endemics can have cascading effects on island ecosystems that are much greater than the loss of single species (O’Dowd et al. 2003, Anderson et al. 2011).
Island populations are more prone to extinction than mainland populations (Frankham et al. 2002), and within island systems, endemic species have higher extinction rates than non-endemic species (Frankham 1998). Conservation of island endemics is essential for minimizing overall impacts of extinction on global biodiversity (Pimm et al. 1995, Jansson 2003). Worldwide, island bird species are particularly at risk, with the majority of avian extinctions since the year 1600 occurring on islands (Johnson and Stattersfield 1990). Island endemic species are often rangerestricted, ecologically naïve (Manne et al. 1999, Charrette et al. 2006, Gibson et al. 2010), and have low genetic variation (Frankham 1997), which makes them especially susceptible to 
emerging infectious diseases (Vitousek 1988, Frankham 1998), invasive species (Simberloff 1995), and climate change (Malcolm et al. 2006, Gibson et al. 2010).

Emerging infectious diseases threaten biodiversity globally (Daszak et al. 2000), but island species may be particularly at risk (Wikelski et al. 2004) because of high population densities, which can facilitate disease transmission (Dobson 1988, Adler 1996), and reduced genetic diversity, which can limit adaptive potential (Mason et al. 2011). Invasive species are common on islands (Sax and Gaines 2008), where they may compose upwards of $50 \%$ of the total species pool (Vitousek et al. 1996). Island species are more sensitive to invasion than mainland species, in part because their limited range restricts escape via dispersal or emigration (Davis 2003). In addition, the low genetic diversity of many island endemic bird species, as well as small ranges and evolved traits like flightlessness and tameness, make island avifauna especially susceptible to novel pressures from invasive species (Jamieson 2007, Clavero et al. 2009). Endemic species are expected to be severely threatened by climate-related extinction (Thuiller et al. 2005, Charrette et al. 2006) because they exhibit traits like range restriction, high specialization, and limited dispersal capability (Isaac et al. 2009, Thomas 2010). Changing climate patterns do not act in isolation; they can also facilitate disease emergence, invasion, and other drivers of extinction for island species (Benning et al. 2002).

The Island Scrub-Jay (Aphelocoma insularis) is the only insular endemic landbird in the continental United States and Canada and is found only on Santa Cruz Island, the largest of the Channel Islands of California (Curry and Delaney 2020). Previous research on Island Scrub-Jay population size and/or trends is somewhat sparse and potentially conflicting. Kelsey and Collins (2000) estimated an island-wide breeding population of $\sim 7000$ birds from bird survey data collected in 1996-1997. Sillett et al. (2012) used bird survey data collected in 2008-2009 and vegetation maps from 1985 and 2005 to estimate an island-wide breeding population of $\sim 1400$ and $\sim 1700$ birds, respectively, at those two time points. These studies relied on limited temporal data to make broader spatial (Kelsey and Collins 2000) or temporal (Sillett et al. 2012) projections. The differing estimates produced by these studies, likely caused by sampling design, modeling strategy, and associated assumptions, highlights the uncertainty surrounding the status of the Island Scrub-Jay population. Given its potentially low population size and small geographic range, the Island Scrub-Jay likely shows island-typical vulnerabilities to diseases, invasive species, and climate change (Morrison et al. 2011, Morrison 2014, Curry and Delaney 2020).

West Nile Virus (WNV) is an emerging infectious disease of birds that has caused avian declines in North America (LaDeau et al. 2007). WNV was first detected in mainland California in 2003 (Reisen et al. 2004). Santa Cruz Island is roughly $40 \mathrm{~km}$ offshore, within the range of overwintering migrant birds that could carry the pathogen to the island. Experimental and field studies have shown that corvids, like the Island Scrub-Jay, are especially susceptible to WNV (Yaremych et al. 2004, Wheeler et al. 2009). A recent simulation study found that the quasi-extinction risk for Island Scrub-Jays increased by $20 \%$ when WNV outbreaks were included compared to WNV-free conditions (Bakker et al. 2020). Some invasive species, e.g., pigs and turkeys, may compete directly with Island Scrub-Jays for acorns, the scrub-jay's primary food source (Parkes et al. 2010, Morrison et al. 2016). In addition, indirect competition by overgrazing, e.g., by sheep, pigs, and turkeys, may reduce breeding habitat and regeneration of important mast-producing vegetation (Peart et al. 1994). Little is known about how variation in precipitation on Santa Cruz Island has influenced Island Scrub-Jay populations, but winter precipitation (lagged one year) can influence acorn production and may also interact with the abundance of mosquito vectors of WNV (Koenig and Knops 2013, Morrison 2014).

Concerns about threats to Island Scrub-Jay populations are ongoing, as are discussions of potential management interventions. Captive rearing and vaccinations (Boyce et al. 2011, Morrison et al. 2011, Bakker et al. 2020) have the potential to bolster populations against threats like disease. Translocations are being considered both to establish an assurance population of Island Scrub-Jays and as an opportunity to improve island scrub oak (Quercus pacifica) regeneration on nearby Santa Rosa Island (Pesendorfer et al. 2018). However, uncertainty about population trends of Island Scrub-Jays hinders effective management action and conservation planning (Morrison 2014). Demographic estimates from a long-term study of this species would aid decision makers in identifying optimal solutions based on their objectives. In fact, continuing and extending studies of endemic vertebrates like the Island Scrub-Jay was recently named a priority for data collection on Santa Cruz Island (Boser et al. 2018).

We used a 20-year dataset on marked Island Scrub-Jays to provide a new perspective on the stability of this species at one study site. Our objectives were to describe long-term trends in adult Island Scrub-Jay survival, recruitment, and population growth at one location and to relate those trends to major drivers of island endemic extinction risk, including disease, invasive species, and winter precipitation. We discuss our findings in the context of other population estimates for Island Scrub-Jays and provide recommendations to managers seeking to conserve Island ScrubJays and other island endemic avifauna.

\section{METHODS}

\section{Study area}

Our study was conducted on land owned by The Nature Conservancy on Santa Cruz Island within Channel Island National Park. Santa Cruz is the largest of the Channel Islands $\left(250 \mathrm{~km}^{2}\right)$ and is $40 \mathrm{~km}$ offshore of Santa Barbara, California $\left(33^{\circ}\right.$ $\left.59^{\prime} 49.19^{\prime \prime} \mathrm{N} 119^{\circ} 43^{\prime} 34.65^{\prime \prime} \mathrm{W}\right)$. The island vegetation is diverse, ranging from oak woodland and chaparral to grassland, coastal scrub, and eucalyptus (Kelsey and Collins 2000). The study site was in the Central Valley of Santa Cruz Island, primarily within a one-mile radius of the Santa Cruz Island Field Station of the University of California Natural Reserve System (Fig. 1). Surveys were conducted within or peripheral to oak woodlands, eucalyptus stands, and chaparral. The isolated pine forest areas found elsewhere on the island were not included in this study (Cohen et al. 2009, Langin et al. 2015).

\section{Study species}

The Island Scrub-Jay is a member of the New World genus Aphelocoma (Pitelka 1945, Curry and Delaney 2020), and its 
genetic distinctness was addressed by Delaney and Wayne (2005). Island Scrub-Jays are territorial and socially monogamous (Atwood 1980), lacking the well-developed cooperative breeding helper system found in the Florida Scrub-Jay (A. coerulescens; Woolfenden and Fitzpatrick 1984) and one population of Woodhouse's Scrub-Jay (A. woodhouseii; Burt and Peterson 1993). Most Island Scrub-Jays do not gain reproductive status until three or more years of age and are non-territorial floaters as pre-breeders (Atwood 1980, Collins and Corey 1994, 2005, Curry and Delaney 2020). Island Scrub-Jays maintain long-term pair bonds and show high site-fidelity, which has been documented by intra-island genetic (Langin et al. 2017) and morphological differences between those inhabiting oak woodlands versus pine forest areas (Langin et al. 2015).

Fig. 1. Map of Santa Cruz Island, California, U.S. showing the location of the study site. The inset map shows the relationship of the Channel Islands to mainland California.

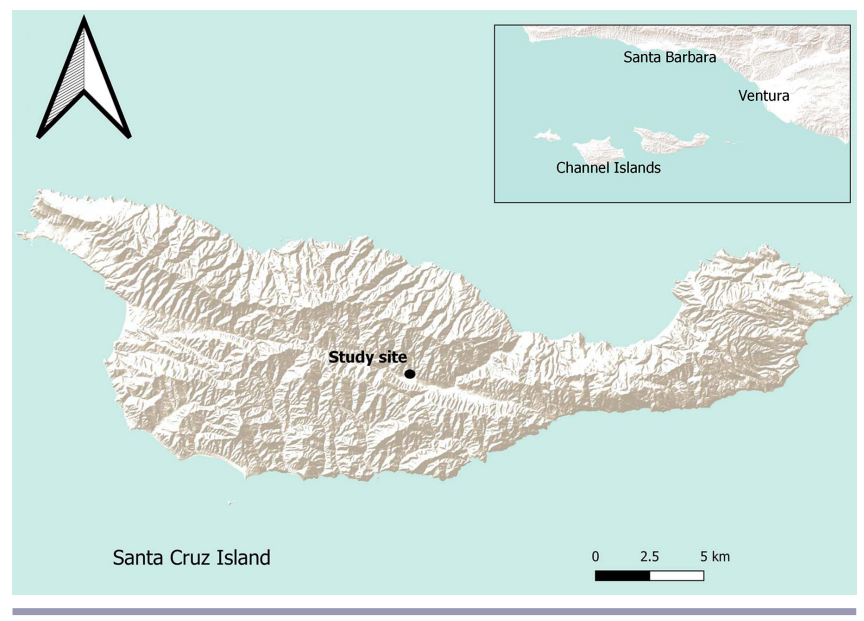

\section{Field sampling}

Every six months (spring and fall) from 1986 to 2007 we captured, color banded, and resighted scrub-jays at the study site. Two to four surveys were conducted each spring and fall, and both captures and resighting occurred on these surveys. Animals were captured using box traps baited with peanuts (Collins and Corey 1994, Kelsey and Collins 2000). The sampling area was surrounded by adjacent suitable habitat, thus the birds sampled were part of a local superpopulation of animals (Crosbie and Manly 1985, Schwarz and Arnason 1996, Williams et al. 2011). Captured animals were aged as juvenile or adult based on plumage (Pitelka 1945) and were uniquely color banded using a combination of three plastic leg bands of five different colors and a numbered U.S. Geological Survey aluminum band. Previously banded scrub-jays were recaptured, when necessary, if any of the bands were broken or missing. Data on wing length, body weight, and sex, if identifiable, were recorded for all captures and recaptures, though some of those data are not used in this analysis.

Observational resighting surveys of territorial pairs as well as non-breeding floaters were conducted, and, sometimes, peanuts were used as bait to bring the birds close enough to read leg bands. Our analysis focused on breeding adults, and we used observations of territorial pairs to help confirm this status. Breeding pairs had very high site fidelity and were usually readily observed during our surveys in the spring (April-May) and fall (September-October). A total of 1514 scrub-jays were banded in this study, of which 677 (44.7\%) were adults of breeding age and form the basis of this analysis. Although surveys were conducted in both the spring and fall, we focus only on the spring sampling period and use data from adult breeders only because our research questions relate to annual trends for adult breeding birds.

\section{Statistical methods}

We used the $f$-parameterization of the Pradel model (Pradel 1996) to estimate annual apparent adult survival probability $(\varphi)$ and recruitment rate $(f)$ while accounting for imperfect detection $(p)$. In addition, we derived estimates of adult population growth rate $(\lambda)$ and seniority $(\gamma)$. Although we estimated apparent survival (which is the complement of mortality combined with emigration), we assume that the high site fidelity of territorial Island Scrub-Jays, and high resighting rate of color-banded pairs, results in estimates that closely approximate true survival. The recruitment rate $(f)$ is the number of new adults in the population at time $t$ per adult in the population at $t-1$, and this rate includes both natural recruitment, i.e., the aging of juveniles to adults, and immigration. The annual adult population growth rate $(\lambda)$ is derived from estimates of $\varphi$ and $f$ in this parameterization $(\lambda=f$ $+\varphi)$ and is the ratio of adults in the population at time $t$ compared to time $t-1$. Values of $\lambda$ greater than 1 suggest a growing population of adult birds, while values less than 1 suggest declining numbers of breeding adults (Pradel 1996). In our context, $\gamma$, or seniority, can be viewed as an analog to $\lambda$ 's elasticity to survival in a matrix modeling approach (Caswell 2001, Nichols and Hines 2002) and can be interpreted as the relative contribution of survival to population growth. We use this parameter to assess whether adult survival or recruitment has the most potential to influence adult population growth.

We note that, with a fully time-varying model, i.e., $\varphi(t) f(t) p(t)$, the first estimates of $p$ and $f$ and the last estimates of $p$ and $\varphi$ can only be jointly estimated and do not have biological interpretations. Likewise, derived estimates of the first and last $\lambda$ do not have biological interpretations with a fully time-dependent model. Our results reflect these constraints. Unless otherwise noted, we present estimates and standard errors.

\section{Predictions}

We generated several predictions about how environmental drivers, like disease, non-native species, and changes in precipitation, might influence Island Scrub-Jay population processes (Table 1). Because of a lack of data on disease intensity and invasive species population sizes on Santa Cruz Island, we constructed hypotheses based on key dates, e.g., first discovery of West Nile Virus in California, date of eradication of sheep (Table 1; Appendix 1). We predicted that, if WNV was affecting Island Scrub-Jays, we would expect to see changes in adult survival coincident with the discovery of WNV on mainland California. We predicted that the presence and/or removal of three invasive species (sheep, pigs, and turkeys) could influence both survival and recruitment of Island Scrub-Jays. Given that acorn production is positively associated with winter precipitation, we predicted that Island Scrub-Jay survival and recruitment would also be positively correlated with winter precipitation and used 
Table 1. Hypothesized effects of covariates on adult Island Scrub-Jay (Aphelocoma insularis) survival $(\varphi)$ and recruitment $(f)$ in a 20year study on Santa Cruz Island, California. For each covariate, at least one hypothesis was generated along with specific rationale (with citations). The hypotheses were then converted to models (Appendix A).

\begin{tabular}{|c|c|c|c|}
\hline Driver & $\begin{array}{l}\text { Parameter(s) } \\
\text { affected }\end{array}$ & Model name: predicted impact on parameter & Rationale \\
\hline $\begin{array}{l}\text { West Nile Virus } \\
\text { (WNV) }\end{array}$ & $\varphi$ & $\begin{array}{l}\text { WNV Trend: constant until } 2003 \text { and then monotonic } \\
\text { decreasing trend } \\
\text { WNV Intercept: constant from 1986-2003, lower, but } \\
\text { constant from 2003-2007 }\end{array}$ & $\begin{array}{l}\text { WNV was discovered } 2003 \text { in CA but was never } \\
\text { detected on Santa Cruz Island (Boyce et al. 2011). }\end{array}$ \\
\hline Sheep (Sheep) & $\varphi$ and/or $f$ & $\begin{array}{l}\text { Sheep Intercept: constant from 1986-1989, higher, but } \\
\text { constant from 1990-2007 } \\
\text { Sheep Trend: constant from 1986-1989, then monotonic } \\
\text { increasing trend }\end{array}$ & $\begin{array}{l}\text { Sheep were introduced to the island in } 1853 \text { and were } \\
\text { extirpated from western part of the island in summer } \\
1989 \text { (Schuyler 1993). }\end{array}$ \\
\hline Pigs (Pig) & $\varphi$ and/or $f$ & $\begin{array}{l}\text { Pig: constant from 1986-2004, higher but constant from } \\
\text { 2005-2007 }\end{array}$ & $\begin{array}{l}\text { Pigs were introduced in the 1850s; eradication began in } \\
\text { March } 2005 \text { and was completed in May } 2006 \text { (Parkes et } \\
\text { al. 2010). }\end{array}$ \\
\hline Turkey (Turkey) & $\varphi$ and/or $f$ & $\begin{array}{l}\text { Turkey: constant from 1986-2000, lower but constant } \\
\text { from 2001-2006 ( } 2007 \text { inestimable in the survival model } \\
\text { due to confounding) }\end{array}$ & $\begin{array}{l}\text { Turkeys were introduced in } 1975 \text {. Populations } \\
\text { stabilized at } 40-50 \text { birds until early } 2000 \text { s when they } \\
\text { increased to } 276 \text { birds in } 2006 \text { and were almost } \\
\text { eradicated in December } 2006 \text {, near our study's end } \\
\text { (Morrison 2007) }\end{array}$ \\
\hline $\begin{array}{l}\text { Precipitation } \\
\text { (Precip) }\end{array}$ & $\varphi$ and/or $f$ & $\begin{array}{l}\text { Precip: positive correlation with continuous covariate of } \\
\text { total winter (November-February) precipitation }\end{array}$ & $\begin{array}{l}\text { Winter precipitation is positively associated with acorn } \\
\text { production in California oaks (Koenig and Knops } \\
\text { 2013). }\end{array}$ \\
\hline Constant (Null) & $\varphi$ and/or $f$ & $\begin{array}{l}\text { Null: no change in survival or recruitment across the } \\
\text { course of the study }\end{array}$ & Island Scrub-Jay population trends may be stable. \\
\hline Trend (Trend) & $\varphi$ and/or $f$ & $\begin{array}{l}\text { Trend: a linear decreasing trend in survival or recruitment } \\
\text { over the course of the study }\end{array}$ & $\begin{array}{l}\text { Additional unmeasured drivers may influence Island } \\
\text { Scrub-Jay survival and/or recruitment. }\end{array}$ \\
\hline
\end{tabular}

winter precipitation data from the Western Regional Climate Center (2019). For comparison, we also fit a model where survival and recruitment were constant and where they followed a linear monotonic trend.

\section{Variance components}

We used a variance components procedure in Program MARK (White and Burnham 1999) to partition the annual variation in estimates of $\lambda, \varphi$, and $f$ into process and sampling variation. Process variation is of biological interest and reflects drivers of vital rate change, but it can often be obscured by sampling variation (Link and Nichols 1994, Gould and Nichols 1998). Long-term datasets, like the one for Island Scrub-Jays, provide an opportunity to partition biological process variation from sampling variation and thus better identify which biological hypotheses explain meaningful variation in parameters of interest. This variance components approach has been employed successfully with long-term datasets for other species, such as with the Northern Spotted Owl (Strix occidentalis caurina; Dugger et al. 2016).

\section{Modeling framework}

Because we focused on a variance components approach, we began with the fully time-varying model $\varphi(t) f(t) p(t)$, which would maximize the amount of temporal process variance in estimates. Using this model, we derived estimates of $\lambda$ for each year and constructed both a constant, i.e., no change over time, and linear trend model for $\lambda$. We identified a trajectory that was consistent with population decline (see Results). To understand which demographic rates were causing the population decline, as well as possible factors affecting those rates, we then built a series of models reflecting biological hypotheses about the influence of disease, invasive species, and winter precipitation patterns on process variation in $\varphi$ and $f$ (Table 1; Appendix 1).

In addition to evaluating hypotheses about these potential drivers of vital rates, we also evaluated a general linear trend model and a constant model for both $\varphi$ and $f$. The variance components approach allows for estimation of the process variance in each parameter, i.e., $\varphi$ and $f$, separately while maintaining the temporal variation in all other parameters. For more information on this approach see Burnham and White (2002).

Finally, we used a different parameterization of the Pradel model to estimate seniority $(\gamma)$ and interpreted $\gamma$ as the proportional contribution of apparent survival to population growth (Nichols and Hines 2002), similar to an elasticity. We used seniority to further understand whether variation or survival or recruitment is the dominant driver of Island Scrub-Jay population growth trends $(\lambda)$.

\section{Software and multimodel inference}

We fit models using Program MARK (White and Burnham 1999) and compared models using Akaike's Information Criterion adjusted for small sample sizes (AICc; Burnham and Anderson 2002), model weights, and the proportion of the process variance explained by each covariate. We calculated the proportion of the process variance explained as the amount of process variation explained by a single model relative to the maximum amount of process variance that could be explained indicated by the intercept-only, constant model, i.e., $\varphi() f.(t) p(t)$ or $\varphi(t) f() p.(t)$. We report the regression coefficient estimates $(\beta)$ for each model on the logit scale with their accompanying standard errors (Table 2). 
Table 2. Model selection results from a mark-recapture study of adult Island Scrub-Jays (Aphelocoma insularis) from 1986 to 2007. We evaluated hypotheses about disease (West Nile Virus, WNV), invasive species (turkey, sheep, and pigs), weather (precipitation), in addition to null and trend models. We estimated adult survival $(\varphi)$ and recruitment $(f)$ using both variance components ("VC") and traditional ("standard") estimation methods. While evaluating hypotheses about survival (or recruitment), we kept recruitment (or survival) and detection probability fully time varying. We present the change in Akaike's Information Criterion adjusted for small sample sizes $(\triangle \mathrm{AICc})$, model weight $\left(w_{\mathrm{i}}\right)$, the number of parameters $(k)$, and deviance for each model. In addition, we present the percent of the process variation explained by the model $\left(\% \sigma^{2}\right)$ and the regression coefficient estimate corresponding to the effect of interest $(\beta)$. Values of N/A in the " $\beta$ " column correspond to models that do not have single effects (e.g. null and time models), while N/ $\mathrm{A}$ in the $\% \sigma^{2}$ explained" column are standard models without variance components.

\begin{tabular}{|c|c|c|c|c|c|c|}
\hline \multicolumn{7}{|c|}{ Adult survival results $(\varphi)$} \\
\hline Turkey 1 - VC & 0.00 & 0.15 & 59.62 & 1751.15 & 0.37 & $-0.14(0.05)$ \\
\hline Sheep Trend - VC & 0.32 & 0.13 & 59.97 & 1750.73 & 0.23 & $-0.01(<0.01)$ \\
\hline Trend - VC & 0.68 & 0.11 & 60.22 & 1750.58 & 0.20 & $-0.01(<0.01)$ \\
\hline Null - VC & 0.73 & 0.10 & 60.29 & 1750.49 & 0.00 & N/A \\
\hline WNV Trend - VC & 0.74 & 0.10 & 60.29 & 1750.49 & 0.09 & $-0.05(0.03)$ \\
\hline WNV Intercept - VC & 0.75 & 0.10 & 60.29 & 1750.50 & 0.07 & $-0.1(0.06)$ \\
\hline Precip - VC & 0.95 & 0.09 & 60.44 & 1750.39 & $\dagger$ & $<0.01(<0.01)$ \\
\hline Sheep Intercept - VC & 0.97 & 0.09 & 60.44 & 1750.41 & $\dagger$ & $0.02(0.07)$ \\
\hline Pig - VC & 1.08 & 0.09 & 60.47 & 1750.45 & 0.01 & $-0.13(0.1)$ \\
\hline Time - standard & 3.45 & 0.03 & 62.00 & 1749.61 & N/A & N/A \\
\hline Null - standard & 113.29 & 0.00 & 42.00 & 1901.12 & N/A & N/A \\
\hline \multicolumn{5}{|c|}{ Adult recruitment results (f) } & $\% \sigma^{2}$ explained & $\beta$ \\
\hline Sheep Trend - VC & 0.00 & 0.12 & 59.40 & 1751.40 & 0.09 & $-0.01(<0.01)$ \\
\hline Trend - VC & 0.00 & 0.12 & 59.39 & 1751.42 & 0.10 & $-0.01(<0.01)$ \\
\hline Precip - VC & 0.01 & 0.12 & 59.42 & 1751.37 & 0.07 & $<0.01(<0.01)$ \\
\hline Null - standard & 0.10 & 0.12 & 59.48 & 1751.33 & 0.00 & N/A \\
\hline Sheep Intercept - VC & 0.17 & 0.11 & 59.30 & 1751.76 & 0.17 & $-0.14(0.06)$ \\
\hline WNV Intercept - VC & 0.37 & 0.10 & 59.67 & 1751.20 & $\dagger$ & $-0.03(0.05)$ \\
\hline Turkey 1 - VC & 0.43 & 0.10 & 59.68 & 1751.24 & 0.07 & $-0.08(0.05), 0.10(0.09)$ \\
\hline Pig $1-\mathrm{VC}$ & 0.48 & 0.10 & 59.73 & 1751.18 & $\dagger$ & $0.06(0.07)$ \\
\hline WNV Trend - VC & 0.50 & 0.09 & 59.76 & 1751.14 & $\dagger$ & $<0.01(0.02)$ \\
\hline Time - standard & 3.67 & 0.02 & 62.00 & 1749.61 & N/A & N/A \\
\hline Null - standard & 61.15 & 0.00 & 42.00 & 1848.76 & N/A & N/A \\
\hline
\end{tabular}

$\dagger$ Indicates models that explained less process variance than the null model.

\section{RESULTS}

We banded a total of 677 breeding adult Island Scrub-Jays over the 22 years of the study. We resighted $68 \%$ of banded scrub-jays at least once, $42 \%$ at least three times, and $15 \%$ more than seven times. The average of number of new individuals banded each year was 31 and was as low as five pairs in 2005, despite a similar level of capture effort. However, these raw numbers need to be corrected for detection probabilities to produce robust estimates of vital rates. We estimated that the probability of detecting a marked individual in the study in any given year averaged 0.73 over our study and ranged from 0.68 to 0.98 [from model $\varphi(t) f(t)$ $p(t) ;$ Fig. 2].

\section{Population growth $(\lambda)$}

After fitting the fully time-varying model $\varphi(t) f(t) p(t)$, we examined the derived estimates of $\lambda$. Population growth was $<$ 1.0 in nine years of study, including five of the six last years of the study, indicating a declining population of scrub-jays at this site (Fig. 3). After factoring out the sampling variance, we estimated the average $\lambda$ over the entire study period to be 0.98 (SE $=0.04$ ) from a constant model, while a linear trend fit to these estimates suggested an annual decline of $1.8 \%$ ( $\mathrm{SE}=0.61 \%$; Fig. 3 , black line). We next focused on testing hypotheses about the
Fig. 2. Detection probability $(p)$ for adult breeding Island Scrub-Jays (Aphelocoma insularis) at one study site on Santa Cruz Island from 1987 to 2006. Detection estimates are from a fully time-varying Pradel model (Pradel 1996) for apparent survival $(\varphi)$, recruitment $(f)$, and detection probability $[\varphi(t) f(t) p$ $(t)$ ]. The first (1986) and last (2007) estimates of detection are confounded in this model and therefore are not depicted. Error bars are standard errors.

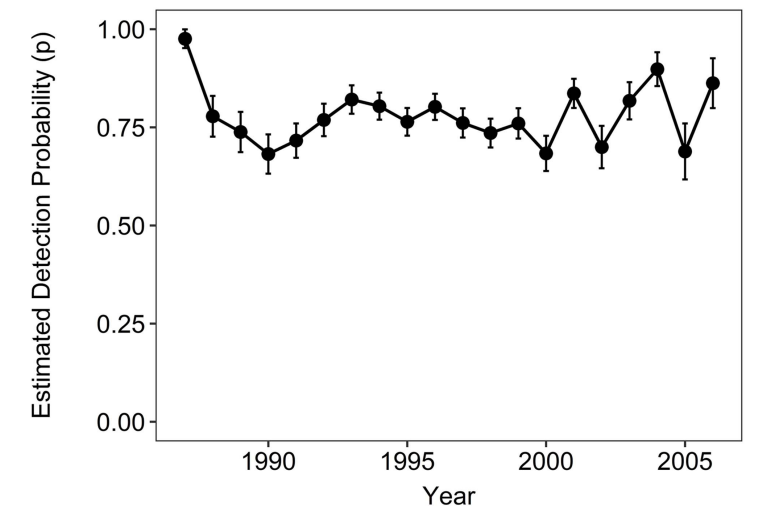


Fig. 3. Long-term population growth trends $(\lambda)$ for Island Scrub-Jays (Aphelocoma insularis) at one study site on Santa Cruz Island. A fully time varying model (grey solid line) estimates population growth rates of less than 1.0 (dashed line) in many years. A linear trend model (black line) estimates an average rate of population decline of $1.8 \%$ per year over this time period. Error bars are standard errors.

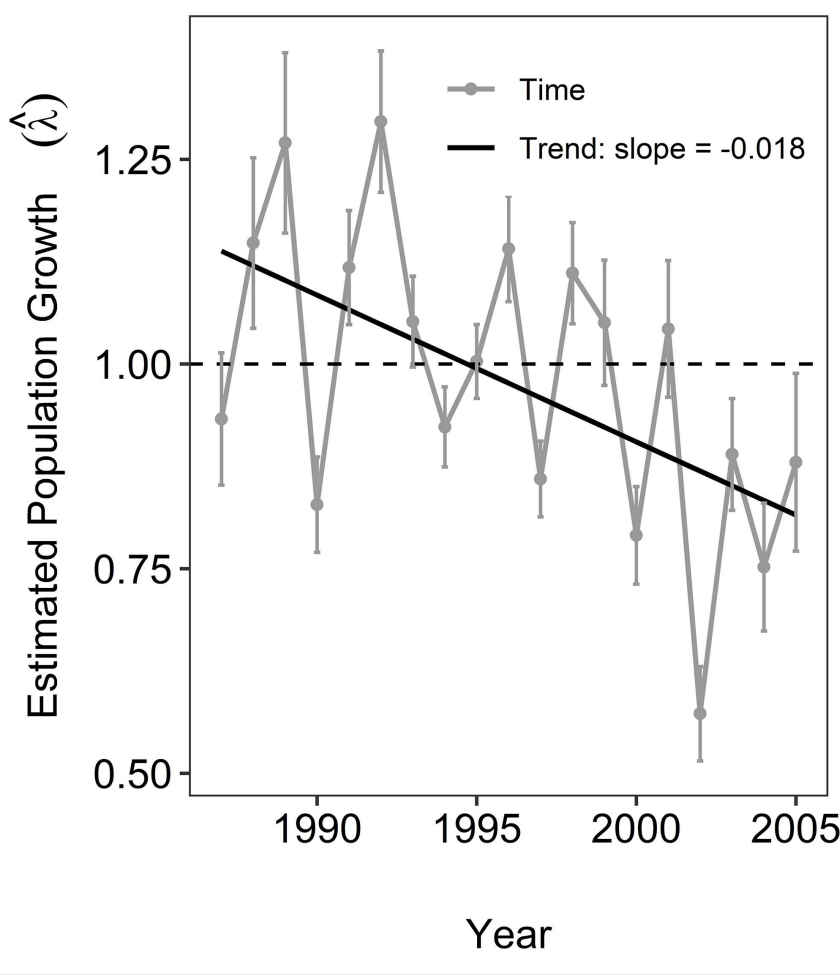

underlying vital rates, i.e., survival and recruitment, to help explain this decline.

\section{Adult survival}

Our variance components approach was an improvement over standard Pradel models, as all the survival variance component models reflecting our hypotheses were better supported than both the time constant $[\varphi() f.(t) p(t)]$ and time-varying $[\varphi(t) f(t) p(t)]$ standard models (Table 2 ). We estimated an adjusted average adult survival of $0.80(\mathrm{SE}=0.02)$ over the time period using variance components [from model $\varphi(t) f(t) p(t)$ ], with lower survival in recent years (Fig. 4, side A). Although our variance components models performed well as a whole for survival, there was little distinction among our hypotheses. The model depicting the increasing turkey population explained the most process variation $(37 \%)$, had the strongest relationship with survival (Table 2$)$, and the effect was in the direction that we hypothesized $(\hat{\beta}=-0.14$ $\pm 0.05)$. The model depicting sheep removal was somewhat supported (Table 2) and explained $23 \%$ of the survival process variation but had a small effect size that was opposite what we predicted $(\hat{\beta}=-0.01 \pm<0.01)$, indicating that survival continued to decline despite sheep removal in 1989. Our hypotheses concerning West Nile Virus, pig eradication, and precipitation effects on survival were not supported (Table 2).
Fig. 4. Annual adult survival (A) and adult recruitment (B) of Island Scrub-Jays (Aphelocoma insularis) at one study site on Santa Cruz Island from 1986 to 2007. Both parameters fluctuate over the course of the study (gray lines) but decline on average (black lines). Error bars are standard errors.
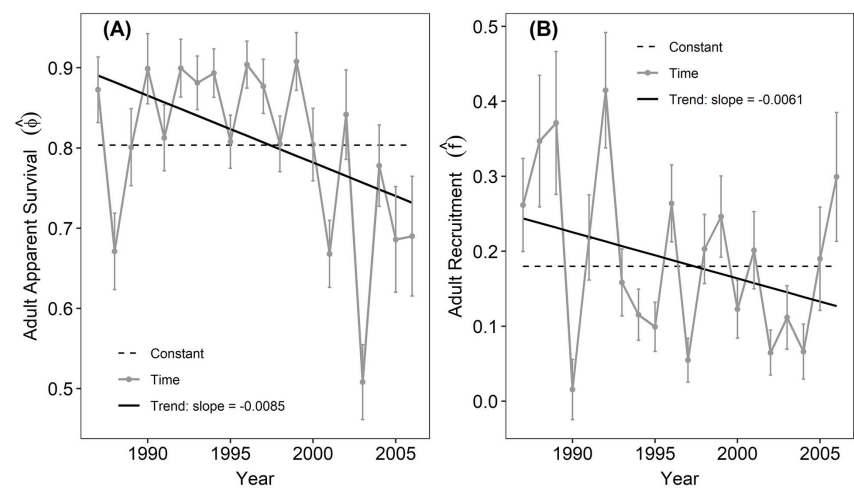

\section{Adult recruitment}

We followed a similar approach to explore which hypotheses would influence adult recruitment. Again, the variance components approach outperformed the standard Pradel models (Table 2). We estimated an average adult recruitment of 0.18 $( \pm 0.02)$ over the study period with lower recruitment more recently (Fig. 4, side B). Unlike survival, few of our covariate models explained much of the total process variation in adult recruitment (Table 2). A monotonic negative trend explained the decline in recruitment as well as any of our hypotheses and suggests an average annual adult recruitment decrease of $0.62 \%$.

\section{Elasticity}

Our average derived estimate of $\gamma[0.82 \pm 0.01$, from standard model $(\varphi(t) p(t) \lambda()$.$] suggests that adult survival has a much larger$ contribution to population growth than does recruitment.

\section{DISCUSSION}

Past density and trend estimates for Island Scrub-Jays have relied on extrapolation through time or space, but suffer from spatial and/or temporal data sparseness. Kelsey and Collins (2000) provided an island-wide abundance estimate based on spatial extrapolation from territory sizes in two study areas surveyed from 1996 to 1997 . This estimate assumed that the two study sites were representative of territories island-wide and did not provide any information about long-term trends. Sillett et al. (2012) used a dataset collected throughout the island in the fall of 2008 and spring of 2009 to estimate total Island Scrub-Jay abundance. Using habitat relationships based on a vegetation map from 2005, they performed a backward projection to 1985 and estimated a $20 \%-30 \%$ increase in scrub-jay abundance from 1985 to 2008 . In both Kelsey and Collins (2000) and Sillett et al. (2012), the authors suggested no immediate concerns about scrub-jay population trends was likely warranted, but their estimates may not be robust to violations of assumptions, especially because static habitatdistribution relationships are seldom accurate depictions of dynamic systems (Yackulic et al. 2015). 
Our study area, based on Sillett et al.'s (2012) predictive mapping, was expected to increase in scrub-jay abundance during a time period that coincides with the timing of our study, yet our results suggested a decline. Specifically, our study at a single location from 1986 to 2007 identified declines in adult breeding Island Scrub-Jays at an average rate of $1.8 \%$ per year, with declines most evident in the later years of the study (2000-2007). This result, while limited in spatial scope, differs from the inferences of Sillett et al. (2012), which suggest an island-wide increase of $20 \%$ to $30 \%$ over a similar time period (from 1985 to 2009). Although scales of data collection differ substantially between the two studies (our study was at a single site for 20 years, while Sillett et al. [2012] collected data at more than 300 survey locations for one year), our results suggest that some circumspection is needed concerning Island Scrub-Jay population dynamics, especially given their island endemism.

Our work suggests that changes in adult apparent survival had a greater proportional impact on population growth than did recruitment, which is expected for organisms like the Island Scrub-Jay that are long-lived, slow to sexually mature, and have relatively few offspring recruit to the adult population (Oli 2004). In general, the average estimate of survival over the course of the study was lower than has been reported in previous studies $(0.80$ compared to 0.94 using 1975-1985 data in Atwood et al. 1990 and 0.91-0.97 using 2008-2012 data in Bakker et al. 2020). However, survival varied annually, ranging from 0.73 to 0.89 . Like Bakker et al. (2020), we estimated apparent survival, which is the probability that animals survive and stay in the study area. Emigration from the study area to other parts of the island, potentially due to recovering vegetation conditions, would result in a reduced apparent survival estimate. However, we observed no case in which a breeding pair left or abandoned their existing territory to establish a new one in a nearby area or one improved by the removal of invasive species. Historically, there were ample non-breeding adult "floaters" in the study area who would quickly replace individuals or pairs from unoccupied or abandoned territories (Collins and Corey 2005), but our findings suggest this was no longer the case in the later years of our study. The work of Bakker et al. (2020) suggests that non-breeding adults have lower apparent survival probabilities than breeding adults (ranging from 0.73 to 0.86 ), potentially reducing the pool of "floaters" available to colonize vacant territories.

Although model selection uncertainty existed based on AICc alone, several models explained process variance. The covariate that explained the most process variance in adult survival was the timing of the increase in the turkey population, explaining $37 \%$ of the variation in survival. Turkeys may have directly competed with Island Scrub-Jays for food resources and may have contributed to overgrazing, which could have influenced Island Scrub-Jay habitat. Eradication efforts for turkeys, sheep, and pigs on Santa Cruz Island have been successful (Parkes et al. 2010, Faulkner and Kessler 2011, Morrison et al. 2016), with turkeys being eradicated from the island in December of 2007, just after our study ended. Evaluating scrub-jay population demographics at this site after turkey eradication may provide additional insights as to the mechanisms of competition at play between these two avian species. However, we note that our study area was in a developed section of the island, and it is possible that scrub-jays in this study area were subject to different threats than other populations on the island.

Although adult recruitment also decreased over the course of our study, particularly from 2000 to 2007 , our hypotheses did not describe this decline any better than a linear negative trend model. Although our elasticity results indicate that adult population growth rate is less sensitive to changes in adult recruitment than to changes in adult apparent survival, it is important to consider possible drivers of this decline in recruitment, especially as they may relate to management interventions. Adult recruitment is the number of new adults in the population at time $t$ compared to the number of adults at time $t-1$. The process of recruiting to the adult population entails entering the population as a juvenile and surviving to adulthood, which can take three to seven years for Island Scrub-Jays (Desrosiers 2014, Curry and Delaney 2020). Therefore, this recruitment decline could ultimately be related to declines in nesting probability, clutch sizes, nest success, juvenile survival, or immigration - all of which can affect the number of breeding adults.

In other island systems, emerging infectious diseases have proven to be a significant threat to endemic avifauna (Thiel et al. 2005, Soares et al. 2017, Samuel et al. 2020). Overall, we found little support for the role of WNV or winter precipitation in shaping Island Scrub-Jay population dynamics. A surveillance program for WNV on Santa Cruz Island took place from 2006 to 2009 and generated 743 negative samples from Island Scrub-Jays and other birds (Boyce et al. 2011). Our findings corroborate the idea that the pathogen was likely not present in the resident scrub-jay population during our study. Still, the number of migrant bird species that overwinter on Santa Cruz Island or pass through on migration, and the prediction that West Nile Virus and other mosquito-vectored pathogens are expected to expand their range because of climate change (LaDeau et al. 2007), indicates that preparing for the emergence of West Nile Virus and other diseases is an important concern for scrub-jay conservation. Boyce et al. (2011) recommended the preemptive vaccination of $\sim 100$ Island Scrub-Jays annually, and Bakker et al. (2020) recommended a combination of translocation and targeted vaccination to continue to buffer Island Scrub-Jays from the potential threat of WNV.

Although we posed hypotheses about several potential threats to Island Scrub-Jays, we were unable to evaluate the role of some other potential threats, including predation risk and lack of genetic diversity. Avian predators of Island Scrub-Jays, including Golden Eagles (Aquila chrysaetos) and overwintering Cooper's Hawks (Accipiter cooperii), likely experienced density changes over the course of our study, which may have impacted survival and recruitment of scrub-jays (Atwood et al. 1990). In addition, Delaney and Wayne (2005) compared Island Scrub-Jay genetics to mainland "Western" Scrub-Jays (including examples of California [A. californica] and Woodhouse's Scrub-Jays), and found that Island Scrub-Jays had less genetic diversity in every metric studied, i.e., allelic diversity, heterozygosity, mitochondrial DNA haplotypes. In addition, Island Scrub-Jays were estimated to have a low effective population size compared to mainland scrub-jay populations (Delaney and Wayne 2005). Without more information on how Island Scrub-Jay genetic diversity has 
changed over time, assessing the role of genetics on scrub-jay population dynamics is difficult. However, populations with low genetic diversity are frequently more prone to inbreeding depression (O'Grady et al. 2006) and are more susceptible to extinction than populations with increased genetic diversity (Frankham 2005).

Though our study population was located at just one site on Santa Cruz Island, the longevity of the dataset makes our inferences especially valuable to managers seeking to ensure robust populations of Island Scrub-Jays into the future as they consider numerous management actions. We believe the data presented here represent the longest temporal dataset for this species. The demographic estimates and trends we provide can serve as a baseline for comparison of vital rates pre- and post- invasive species removal, as climate continues to change, and for effects of WNV if the disease arrives on the island (Boser et al. 2018). Our trend estimates provide essential context for management interventions that are currently being considered, including translocations, vaccinations, and captive rearing (Morrison 2014, Pesendorfer et al. 2018, Bakker et al. 2020).

For instance, the establishment of a captive population on mainland California and/or a wild population on neighboring Santa Rosa Island, where scrub-jays historically occurred, is currently being considered (Collins 2009, Morrison et al. 2011). These actions might serve to hedge against possible threats on Santa Cruz Island (Morrison et al. 2011), including the arrival of West Nile Virus (Bakker et al. 2020). In addition, the repatriation of scatter-hoarding Island Scrub-Jays to Santa Rosa Island could help meet other management objectives related to the recovery of oak woodlands on the island (Pesendorfer et al. 2016). Future introductions of non-native predators are another concern for Island Scrub-Jay conservation. Biosecurity concerns, especially for a response to rat introduction to the island, continue to exist (Boser et al. 2014).

The Island Scrub-Jay is not currently considered a species of concern at the state, federal, or global (International Union for Conservation of Nature, IUCN) level, even though the species population size is likely small, restricted, and potentially under threat. Long-term and standardized monitoring of this population remains important and we note that a populationwide survey has not occurred since Sillett et al.'s work (2012). Such a survey would contribute much to our understanding of the status of the species.

Responses to this article can be read online at: https://www.ace-eco.org/issues/responses.php/1997

\section{Author Contributions:}

C.T.C., B.A.M., and P.J.D. formulated the questions; C.T.C., J.L. A., and K. A.C. collected data; C.T.C. supervised research; B. A.M. and P.J.D. analyzed the data; and B.A.M. wrote the paper with editing from all authors.

\section{Acknowledgments:}

We are grateful to the Nature Conservancy and the University of California Natural Reserve System for permission to carry out this study on Santa Cruz Island and the use of the facilities of the Channel Island Field Station. We are indebted to the numerous observers who spent time with us over the years in pursuit of colorbanded jays. Above all, we want to express our gratitude to Lyndal Laughrin for his logistical support and friendship over the years while we were conducting this study.

\section{LITERATURE CITED}

Adler, G. H. 1996. The island syndrome in isolated populations of a tropical forest rodent. Oecologia 108:694-700. https://doi. org/10.1007/BF00329044

Anderson, S. H., D. Kelly, J. J. Ladley, S. Molloy, and J. Terry. 2011. Cascading effects of bird functional extinction reduce pollination and plant density. Science 331:1068-1071. https://doi. org/10.1126/science.1199092

Atwood, J. L. 1980. Social interactions in the Santa Cruz Island Scrub Jay. Condor 82(4):440-448. https://doi.org/10.2307/1367571

Atwood, J. L., M. J. Elpers, and C. T. Collins. 1990. Survival of breeders in Santa Cruz Island and mainland California Scrub Jay populations. Condor 92(3):783-788. https://doi.org/10.2307/1368703

Bakker, V. J., T. S. Sillett, W. M. Boyce, D. F. Doak, T. W. Vickers, W. K. Reisen, B. S. Cohen, M. T. Hallworth, and S. A. Morrison. 2020. Translocation with targeted vaccination is the most effective strategy to protect an island endemic bird threatened by West Nile virus. Diversity and Distributions 26:1104-1115. https://doi. org/10.1111/ddi.13109

Benning, T. L., D. LaPointe, C. T. Atkinson, and P. M. Vitousek. 2002. Interactions of climate change with biological invasions and land use in the Hawaiian Islands: modeling the fate of endemic birds using a geographic information system. Proceedings of the National Academy of Sciences 99:14246-14249. https://doi.org/10.1073/pnas.162372399

Boser, C. L., C. Cory, K. R. Faulkner, J. M. Randall, J. J. Knapp, and S. A. Morrison. 2014. Strategies for biosecurity on a nearshore island in California. Monographs of the Western North American Naturalist 7:412-420. https://doi.org/10.3398/042.007.0131

Boser, C. L., T. S. Sillett, P. W. Collins, K. R. Faulkner, W. C. Funk, C. K. Ghalambor, L. Laughrin, G. B. Pauly, J. M. Robertson, R. Shea, and W. Vickers. 2018. Equipping tomorrow's historical ecologist: priorities for documenting conditions of the terrestrial fauna of Santa Cruz Island, California. Western North American Naturalist 78:879-887. https://doi.org/10.3398/064.078.0426

Boyce, W. M., W. Vickers, S. A. Morrison, T. S. Sillett, L. Caldwell, S. S. Wheeler, C. M. Barker, R. Cummings, and W. K. Reisen. 2011. Surveillance for West Nile Virus and vaccination of freeranging Island Scrub-Jays (Aphelocoma insularis) on Santa Cruz Island, California. Vector-Borne and Zoonotic Diseases 11:1063-1068. https://doi.org/10.1089/vbz.2010.0171 
Burnham, K. P., and D. R. Anderson. 2002. Model selection and multimodel inference: a practical information-theoretic approach. Springer Verlag, New York, New York, USA. https:// doi.org/10.1007/b97636

Burnham, K. P., and G. C. White. 2002. Evaluation of some random effects methodology applicable to bird ringing data. Journal of Applied Statistics 29:245-264. https://doi. org/10.1080/02664760120108755

Burt, D. B., and A. T. Peterson. 1993. Biology of cooperativebreeding Scrub Jays (Aphelocoma coerulescens) of Oaxaca, Mexico. Auk 110:207-214. [online] URL: https://sora.unm.edu/ sites/default/files/journals/auk/v110n02/p0207-p0214.pdf

Caswell, H. 2001. Matrix population models: construction, analysis, and interpretation. Sinauer Associates, Inc, Sunderland, Massachusetts, USA.

Charrette, N. A., D. F. R. Cleary, and A. Ø. Mooers. 2006. Rangerestricted, specialist Bornean butterflies are less likely to recover from ENSO-induced disturbance. Ecology 87(9):2330-2337. https://doi.org/10.1890/0012-9658(2006)87[2330:RSBBAL]2.0.CO;2

Clavero, M., L. Brotons, P. Pons, and D. Sol. 2009. Prominent role of invasive species in avian biodiversity loss. Biological Conservation 142:2043-2049. https://doi.org/10.1016/j.biocon.2009.03.034

Cohen, B., Cory, C., Menke, J., and Hepburn, A. 2009. A spatial database of Santa Cruz Island Vegetation. Pages 229-244 in C. C. Damiani and D. K. Garcelon, editors. Proceedings of the 7 th California Islands Syposium. Institute for Wildlife Studies, Arcata, California, USA. [online] URL: https://static1. squarespace.com/static/60a6b9c6059cad3139d4d98b/ t/615dd69cbd90b0122fae3861/1633539741302/Cohen_et_al.pdf

Collins, C. T., and K. Corey. 1994. Delayed breeding in the Santa Cruz Island Scrub Jay: why not be cooperative? Pages 371-378 in W. L. Halverson and G. J. Maender. Fourth California islands symposium: update on the status of resources. Santa Barbara Museum of Natural History, Santa Barbara, California, USA.

Collins, C. T., and K. A. Corey. 2005. Territory acquisition by island Scrub-Jays: how to become a breeder. Pages 257-262 in D. Garcelon, and C. A. Schwemm, editors. Proceedings of the Sixth California Islands Symposium. National Park Service Technical Publication CHIS-05-01. Institute for Wildlife Studies, Arcata, California, USA.

Collins, P. W. 2009. Historic and prehistoric record for the occurrence of island scrub-jays (Aphelocoma insularis) on the Northern Channel Islands, Santa Barbara County, California. Santa Barbara Museum of Natural History Technical ReportsNo.5, Santa Barbara, California, USA. [online] URL: https:// www.nps.gov/chis/learn/nature/upload/ISSJ_HistoryReport_SBMNHTechReport5.pdf

Crosbie, S. F., and B. F. J. Manly. 1985. Parsimonious modelling of capture-mark-recapture studies. Biometrics 41(2):385-398. https://doi.org/10.2307/2530864

Curry, R. L., and K. S. Delaney. 2020. Island Scrub-Jay (Aphelocoma insularis), version 1.0. In A. F. Poole and F. B. Gill, editors. Birds of the world. Cornell Lab of Ornithology, Ithaca, New York, USA. https://doi.org/10.2173/bow.issjay.01
Daszak, P., A. A. Cunningham, and A. D. Hyatt. 2000. Emerging infectious diseases of wildlife-threats to biodiversity and human health. Science 287:443-449. https://doi.org/10.1126/science.287.5452.443

Davis, M. A. 2003. Biotic globalization: does competition from introduced species threaten biodiversity? BioScience 53 (5):481-489. https://doi.org/10.1641/0006-3568(2003)053[0481: BGDCFI]2.0.CO;2

Delaney, K. S., and R. K. Wayne. 2005. Adaptive units for conservation: population distinction and historic extinctions in the Island Scrub-Jay. Conservation Biology 19:523-533. https:// doi.org/10.1111/j.1523-1739.2005.00424.X

Desrosiers, M. A. 2014. Body size, first-year breeding and extrapair paternity in an island endemic, the Island Scrub-Jay. Thesis. Colorado State University, Fort Collins, Colorado, USA. [online] URL https://mountainscholar.org/bitstream/handle/10217/82547/ Desrosiers_colostate_0053N_12249.pdf?sequence=1\&isAllowed= y

Dobson, A. P. 1988. Restoring island ecosystems: the potential of parasites to control introduced mammals. Conservation Biology 2(1):31-39. https://doi.org/10.1111/j.1523-1739.1988. tb00333.x

Dugger, K. M., E. D. Forsman, A. B. Franklin, R. J. Davis, G. C. White, C. J. Schwarz, K. P. Burnham, J. D. Nichols, J. E. Hines, C. B. Yackulic, P. F. Doherty, L. Bailey, D. A. Clark, S. H. Ackers, L. S. Andrews, B. Augustine, B. L. Biswell, J. Blakesley, P. C. Carlson, M. J. Clement, L. V. Diller, E. M. Glenn, A. Green, S. A. Gremel, D. R. Herter, J. M. Higley, J. Hobson, R. B. Horn, K. P. Huyvaert, C. McCafferty, T. McDonald, K. McDonnell, G. S. Olson, J. A. Reid, J. Rockweit, V. Ruiz, J. Saenz, and S. G. Sovern. 2016. The effects of habitat, climate, and Barred Owls on longterm demography of Northern Spotted Owls. Condor 118 (1):57-116. https://doi.org/10.1650/CONDOR-15-24.1

Faulkner, K. R., and C. C. Kessler. 2011. Live removal of feral sheep from eastern Santa Cruz Island, California. Pages 295-299 in C. R Veitch., M. N. Clout, and D. R Towns, editors. Island invasives: eradication and management. IUCN, Gland, Switzerland.

Frankham, R. 1997. Do island populations have less genetic variation than mainland populations? Heredity 78(3):311-327. https://doi.org/10.1038/hdy.1997.46

Frankham, R. 1998. Inbreeding and extinction: island populations. Conservation Biology 12:665-675. https://doi. org/10.1046/j.1523-1739.1995.09040792.x

Frankham, R. 2005. Genetics and extinction. Biological Conservation 126:131-140. https://doi.org/10.1016/j.biocon.2005.05.002

Frankham, R., D. A. Briscoe, and J. D. Ballou. 2002. Introduction to conservation genetics. Cambridge University Press, Cambridge, UK.

Gibson, L., A. McNeill, P. de Tores, A. Wayne, and C. Yates. 2010. Will future climate change threaten a range restricted endemic species, the quokka (Setonix brachyurus), in south west Australia? Biological Conservation 143(11):2453-2461. https://doi.org/10.1016/ j.biocon.2010.06.011 
Gould, W. R., and J. D. Nichols. 1998. Estimation of temporal variability of survival in animal populations. Ecology 79:2531-2538. https://doi.org/10.2307/176841

Isaac, J. L., J. Vanderwal, C. N. Johnson, and S. E. Williams. 2009. Resistance and resilience: quantifying relative extinction risk in a diverse assemblage of Australian tropical rainforest vertebrates. Diversity and Distributions 15:280-288. https://doi.org/10.1111/ j.1472-4642.2008.00531.x

Jamieson, I. G. 2007. Has the debate over genetics and extinction of island endemics truly been resolved? Animal Conservation 10 (2):139-144. https://doi.org/10.1111/j.1469-1795.2006.00095.x

Jansson, R. 2003. Global patterns in endemism explained by past climatic change. Proceedings of the Royal Society of London B: Biological Sciences 270(1515):583-590. https://doi.org/10.1098/ rspb.2002.2283

Johnson, T. H., and A. J. Stattersfield. 1990. A global review of island endemic birds. Ibis 132:167-180. https://doi.org/10.1111/ j.1474-919X.1990.tb01036.X

Kelsey, R., and C. T. Collins. 2000. Estimated population size of the Island Scrub-Jay Aphelocoma insularis. Bird Conservation International 10(2):137-148. https://doi.org/10.1017/S0959270900000137

Koenig, W. D., and J. M. H. Knops. 2013. Large-scale spatial synchrony and cross-synchrony in acorn production by two California oaks. Ecology 94:83-93. https://doi.org/10.1890/12-0940.1

LaDeau, S. L., A. M. Kilpatrick, and P. P. Marra. 2007. West Nile virus emergence and large-scale declines of North American bird populations. Nature 447(7145):710-713. https://doi.org/10.1038/ nature05829

Langin, K. M., T. S. Sillett, W. C. Funk, S. A. Morrison, M. A. Desrosiers, and C. K. Ghalambor. 2015. Islands within an island: repeated adaptive divergence in a single population. Evolution 69:653-665. https://doi.org/10.1111/evo.12610

Langin, K. M., T. S. Sillett, W. C. Funk, S. A. Morrison, and C. K. Ghalambor. 2017. Partial support for the central-marginal hypothesis within a population: reduced genetic diversity but not increased differentiation at the range edge of an island endemic bird. Heredity 119:8-15. https://doi.org/10.1038/hdy.2017.10

Link, W. A., and J. D. Nichols. 1994. On the importance of sampling variance to investigations of temporal variation in animal population size. Oikos 69(3):539-544. https://doi. org/10.2307/3545869

MacArthur, R. H., and E. O. Wilson. 1967. The theory of island biogeography, Princeton University Press, Princeton, New Jersey, USA.

Malcolm, J. R., C. Liu, R. P. Neilson, L. Hansen, and L. Hannah. 2006. Global warming and extinctions of endemic species from biodiversity hotspots. Conservation Biology 20(2):538-548. https://doi.org/10.1111/j.1523-1739.2006.00364.x

Manne, L. L., T. M. Brooks, and S. L. Pimm. 1999. Relative risk of extinction of passerine birds on continents and islands. Nature 399(6733):258-261. https://doi.org/10.1038/20436
Mason, R. A. B., T. L. Browning, and M. D. B. Eldridge. 2011. Reduced MHC class II diversity in island compared to mainland populations of the black-footed rock-wallaby (Petrogale lateralis lateralis). Conservation Genetics 12:91-103. https://doi. org/10.1007/s10592-009-9993-y

Morrison, S. A. 2007. Reducing risk and enhancing efficiency in non-native vertebrate removal efforts on islands: a 25 year multitaxa retrospective from Santa Cruz Island, California. Pages 398-409 in G. W. Witmer, W. C. Pitt, and K. A. Fagerstone, editors. Managing vertebrate invasive species: proceedings of an international symposium. USDA/APHIS Wildlife Services, National Wildlife Research Center, Fort Collins, Colorado, USA. [online] URL: https://digitalcommons.unl.edu/cgi/viewcontent. cgi? article $=1030 \&$ context $=$ nwrcinvasive

Morrison, S. A. 2014. A bird in our hand: weighing uncertainty about the past against uncertainty about the future in Channel Islands National Park. George Wright Forum 31(1):77-93. [online] URL: http://www.georgewright.org/311morrison.pdf

Morrison, S. A., A. J. DeNicola, K. Walker, D. Dewey, L. Laughrin, R. Wolstenholme, and N. Macdonald. 2016. An irruption interrupted: eradication of Wild Turkeys Meleagris gallopavo from Santa Cruz Island, California. Oryx 50 (1):121-127. https://doi.org/10.1017/S0030605314000428

Morrison, S. A., T. S. Sillett, C. K. Ghalambor, J. W. Fitzpatrick, D. M. Graber, V. J. Bakker, R. Bowman, C. T. Collins, P. W. Collins, K. S. Delaney, et al. 2011. Proactive conservation management of an island-endemic bird species in the face of global change. BioScience 61:1013-1021. https://doi.org/10.1525/bio.2011.61.12.11

Nichols, J. D., and J. E. Hines. 2002. Approaches for the direct estimation of lambda, and demographic contributions to lambda, using capture-recapture data. Journal of Applied Statistics 29:539-568. https://doi.org/10.1080/02664760120108809

O’Dowd, D. J., P. T. Green, and P. S. Lake. 2003. Invasional 'meltdown'on an oceanic island. Ecology Letters 6(9):812-817. https://doi.org/10.1046/j.1461-0248.2003.00512.x

O'Grady, J. J., B. W. Brook, D. H. Reed, J. D. Ballou, D. W. Tonkyn, and R. Frankham. 2006. Realistic levels of inbreeding depression strongly affect extinction risk in wild populations. Biological Conservation 133:42-51. https://doi.org/10.1016/j. biocon.2006.05.016

Olesen, J. M., L. I. Eskildsen, and S. Venkatasamy. 2002. Invasion of pollination networks on oceanic islands: importance of invader complexes and endemic super generalists. Diversity and Distributions 8:181-192. https://doi.org/10.1046/j.1472-4642.2002.00148. $\mathrm{X}$

Oli, M. K. 2004. The fast-slow continuum and mammalian lifehistory patterns: an empirical evaluation. Basic and Applied Ecology 5:449-463. https://doi.org/10.1016/j.baae.2004.06.002

Parkes, J. P., D. S. Ramsey, N. Macdonald, K. Walker, S. McKnight, B. S. Cohen, and S. A. Morrison. 2010. Rapid eradication of feral pigs (Sus scrofa) from Santa Cruz Island, California. Biological Conservation 143(3):634-641. https://doi. org/10.1016/j.biocon.2009.11.028 
Peart, D., D. T. Patten, and S. L. Lohr. 1994. Feral pig disturbance and woody species seedling regeneration and abundance beneath coast live oaks (Quercus agrifolia) on Santa Cruz Island, California. Pages 313-321 in W. L. Havorson, and G.L. Maender, editors. The Fourth California Islands Symposium: Update on the Status of Resources. Santa Barbara Museum of Natural History, Santa Barbara, California, USA.

Pesendorfer, M. B., C. M. Baker, M. Stringer, E. McDonaldMadden, M. Bode, A. K. McEachern, S. A. Morrison, T. S. Sillett, and M. D. Mateos. 2018. Oak habitat recovery on California's largest islands: scenarios for the role of corvid seed dispersal. Journal of Applied Ecology 55:1185-1194. https://doi. org/10.1111/1365-2664.13041

Pesendorfer, M. B., T. S. Sillett, and S. A. Morrison. 2016. Spatially-biased dispersal of acorns by a scatter-hoarding corvid may accelerate passive restoration of oak habitat on California's largest island. Current Zoology 63:363-367. https://doi. org/10.1093/cz/zow075

Pimm, S. L., G. J. Russell, J. L. Gittleman, and T. M. Brooks. 1995. The future of biodiversity. Science 269:347-350. https://doi. org/10.1126/science.269.5222.347

Pitelka, F. A. 1945. Pterylography, molt, and age determination of American jays of the genus Aphelocoma. Condor 47:229-260. https://doi.org/10.2307/1364056

Pradel, R. 1996. Utilization of capture-mark-recapture for the study of recruitment and population growth rate. Biometrics 52 (2):703-709. https://doi.org/10.2307/2532908

Reisen, W., H. Lothrop, R. Chiles, M. Madon, C. Cossen, L. Woods, S. Husted, V. Kramer, and J. Edman. 2004. West Nile Virus in California. Emerging Infectious Diseases 10:1369-1378. https://doi.org/10.3201/eid1008.040077

Samuel, M. D., W. Liao, C. T. Atkinson, and D. A. LaPointe. 2020. Facilitated adaptation for conservation - Can gene editing save Hawaii's endangered birds from climate driven avian malaria? Biological Conservation 241:108390. https://doi.org/10.1016/j. biocon.2019.108390

Sax, D. F., and S. D. Gaines. 2008. Species invasions and extinction: the future of native biodiversity on islands. Proceedings of the National Academy of Sciences 105:11490-11497. https://doi.org/10.1073/pnas.0802290105

Schuyler, P. 1993. Control of feral sheep (Ovis aries) on Santa Cruz Island, California. Pages 443-452 in F. G. Hochberg, editor. Advances in California Islands research: proceedings of the third California Islands Symposium. Santa Barbara Museum of Natural History, Santa Barbara, California, USA.

Schwarz, C. J., and A. N. Arnason. 1996. A general methodology for the analysis of capture-recapture experiments in open populations. Biometrics 52(3):860-873. https://doi.org/10.2307/2533048

Sillett, T. S., R. B. Chandler, J. A. Royle, M. Kéry, and S. A. Morrison. 2012. Hierarchical distance-sampling models to estimate population size and habitat-specific abundance of an island endemic. Ecological Applications 22:1997-2006. https:// doi.org/10.1890/11-1400.1
Simberloff, D. 1995. Why do introduced species appear to devastate islands more than mainland areas? Pacific Science 49:87-97. [online] URL: http://hdl.handle.net/10125/2276

Soares, L., P. Marra, L. Gray, and R. E. Ricklefs. 2017. The malaria parasite Plasmodium relictum in the endemic avifauna of eastern Cuba. Conservation Biology 31:1477-1482. https://doi. org/10.1111/cobi.12995

Thiel, T., N. K. Whiteman, A. Tirapé, M. I. Baquero, V. Cedeño, T. Walsh, G. J. Uzcátegui, and P. G. Parker. 2005. Characterization of canarypox-like viruses infecting endemic birds in the Galápagos Islands. Journal of Wildlife Diseases 41:342-353. https://doi.org/10.7589/0090-3558-41.2.342

Thomas, C. D. 2010. Climate, climate change and range boundaries. Diversity and Distributions 16:488-495. https://doi. org/10.1111/j.1472-4642.2010.00642.x

Thuiller, W., S. Lavorel, and M. B. Araújo. 2005. Niche properties and geographical extent as predictors of species sensitivity to climate change. Global Ecology and Biogeography 14:347-357. https://doi.org/10.1111/j.1466-822X.2005.00162.x

Vitousek, P. M. 1988. Diversity and biological invasions of oceanic islands. Pages 181-189 in E.O. Wilson and F. M. Peter, editors. Biodiversity. National Academies Press, Washington, D. C., USA.

Vitousek, P. M., C. M. D Antonio, L. L. Loope, and R. Westbrooks. 1996. Biological invasions as global environmental change. American Scientist 84(5):218-228. [online] URL: https:// pubag.nal.usda.gov/download/61/pdf

Western Regional Climate Center. 2019. Santa Cruz, California. [online] URL: https://wrcc.dri.edu/

Wheeler, S. S., C. M. Barker, Y. Fang, M. V. Armijos, B. D. Carroll, S. Husted, W. O. Johnson, and W. K. Reisen. 2009. Differential impact of West Nile virus on California birds. Condor 111:1-20. https://doi.org/10.1525/cond.2009.080013

White, G. C., and K. P. Burnham. 1999. Program MARK: survival estimation from populations of marked animals. Bird Study 46: S120-S139. https://doi.org/10.1080/00063659909477239

Whittaker, R. J., and J. M. Fernández-Palacios. 2007. Island biogeography: ecology, evolution, and conservation. Oxford University Press, Oxford, UK.

Wikelski, M., J. Foufopoulos, H. Vargas, and H. Snell. 2004. Galápagos birds and diseases: invasive pathogens as threats for island species. Ecology and Society 9(1):5. https://doi. org/10.5751/ES-00605-090105

Williams, K. A., P. C. Frederick, and J. D. Nichols. 2011. Use of the superpopulation approach to estimate breeding population size: an example in asynchronously breeding birds. Ecology 92:821-828. https://doi.org/10.1890/10-0137.1

Woolfenden, G. E., and J. W. Fitzpatrick. 1984. The Florida scrub jay: demography of a cooperative-breeding bird. Princeton University Press, Princeton, New Jersey, USA.

Yackulic, C. B., J. D. Nichols, J. Reid, and R. Der. 2015. To predict the niche, model colonization and extinction. Ecology 96 (1):16-23. https://doi.org/10.1890/14-1361.1 
Yaremych, S. A., R. E. Warner, P. C. Mankin, J. D. Brawn, A. Raim, and R. Novak. 2004. West Nile virus and high death rate in American Crows. Emerging Infectious Diseases 10(4):709-711. https://doi.org/10.3201/eid1004.030499

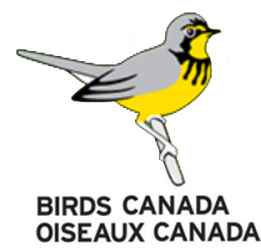


Appendix 1. Visual depictions of the design matrices used to model each prediction in Table 1. Design matrices are provided for both survival and recruitment.

Please click here to download file 'appendix1.xlsx'. 